\title{
CONCEPT OF UNDERGROUND GAS STORAGE IN THE LIMESTONE ROCKS IN SLOVENIA
}

\section{Željko Vukelić1, Milivoj Vulić}

1 University of Ljubljana, Faculty of Natural Sciences and Engineering, Aškerčeva 12, 1000 Ljubljana, Slovenia, e-mail: zeljko.vukelic@ntf.uni-lj.si; milivoj.vulic@guest.arnes.si

Received: 2018.05.15

Accepted: 2018.08.01

Published: 2018.09.01

\begin{abstract}
The paper provides research and results for underground storage of gas (UGSG) in limestone rocks, which were carried out in Slovenia - Central Europe. The areas was geological surveyed and in addition structural boreholes were drilled up to the depth of $350 \mathrm{~m}$. The cores were logged with emphasis on stratigraphy, layering, rock joints, tectonic zones, RQD... and addition characteristics samples were taken for the laboratory rocks geomechanical characteristics investigations. In boreholes geophysical, pressiometric and hydro-geological investigations were also carried out. In the area where the researches have been carried out, limestone, dolomites and breccias are prevalent. Storage should be built for pressure between 15 and $20 \mathrm{MPa}$. Explorations confirmed that there is a possibility of building a high-pressure underground storage of gas (UGSG) and using applied mechanics for design LRC (Lined Rock Cavern) technology. The construction of underground storage facilities for natural gas storage is important in cases, where the gas supply does not meet the required capacity for operation of the thermal power plant.
\end{abstract}

Keywords: underground storage of gas, lined rock cavern, limestone, elastic modulus.

\section{INTRODUCTION}

Slovenian gas supply system has stores of natural gas leased abroad. Thermal power station Brestanica (TEB) is one of larger consumers of natural gas in Slovenia but with its way of operating as a typical peak power station with huge hourly and daily consumptions, which cause, in a relatively small gas supply system, substantial problems, particularly in winter. Winter is also season, when limitations of TEB's operation occur due to large consumption of gas. Therefore, we started with field and laboratory researches a few years ago. Researches involved geological mapping of the surface, structural drilling of few deep boreholes on the core, field geo-technical measurements in boreholes (pressiometer, geo-physical measurements, hydro geological measure- ments) and laboratory researches of borehole cores for determination of their geomechanical parameters. In the area where the researches have been carried out, limestone, dolomites and breccia's are prevalent. Explorations confirmed that there is a possibility of building a highpressure underground storage of gas (UGSG) using applied mechanics for LRC (Lined Rock Cavern) technology [1]. For UGSG three access tunnels in three different levels are built first. When access tunnels are made, excavation of the underground cavern of projected dimensions can start. Next, a steel cavern lining must be created (thickness of the wainscot lining is $12-15 \mathrm{~mm}$ ). Space between the hill and steel lining is filled with concrete. Underground cavern is connected to the surface by a vertical shaft with tubes for filling, cooling and emptying gas from the underground storage. 


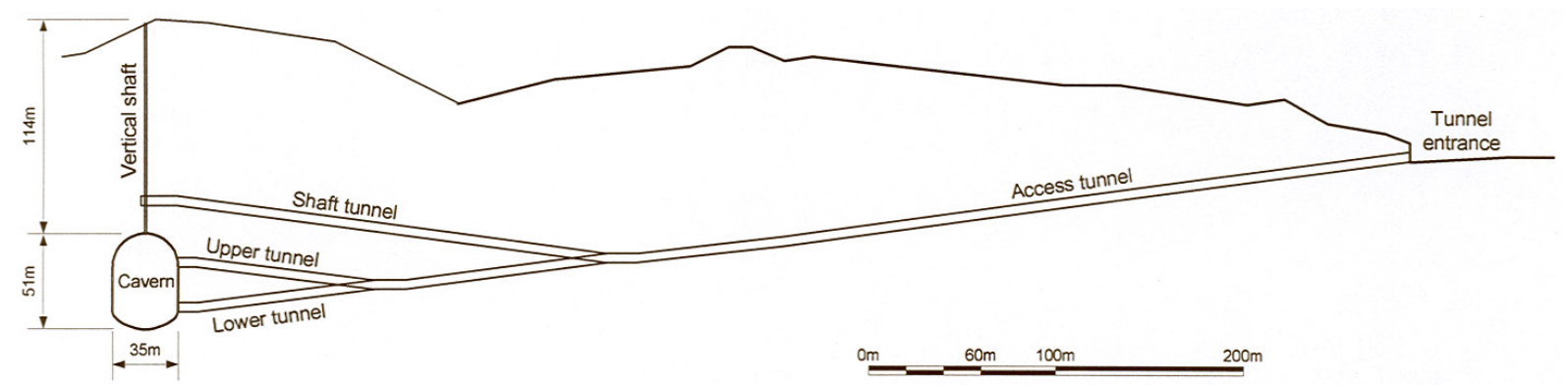

Fig. 1. Schematic view of the underground natural gas storage UGSG

\section{CONCEPT OF LRC UNDERGROUND STORAGE}

The design of the considered LRC structure is typical, see Figure 1, Figure 2. The LRC consists from the cylindrical wall and the upper and lower spheres. The caverns are typically 50 to $100 \mathrm{~m}$ high and are located at depths from 100 to $300 \mathrm{~m}$. Their concept involves relatively large diameters: between 10 and $50 \mathrm{~m}$. The concrete wall is 2 or more meters thick, the thickness of the steel lining amounts from 12 to $15 \mathrm{~mm}$. Applied mechanics is a tool for designing a steel lining $[2,3,4]$.

It is expected that the gas pressure cyclically increases and decreases during periods of gas supply and discharge between the minimal (15 $\mathrm{MPa}$ ) and maximal $20 \mathrm{MPa}$ value $[5,6,7]$. The internal pressure therefore causes static and cyclic loads. The minimum lifetime of the LRC is limited to be higher than 500 cycles. Since caverns are constructed at the depths between 100 and $300 \mathrm{~m}$, the hydrostatic pressure reaches 1 to $3 \mathrm{MPa}$. Drainage system is installed on the outer side of the cavern wall. It drainages the water and enables the monitoring, collection and removing of the gas in the case of gas leakage.

The system of tunnels is designed in order to transport material and allow the access for machinery during the construction of the underground chambers. The tunnels also provide a cost-effective mining of caverns. Cross-section of tunnels amounts about $25 \mathrm{~m}^{2}$ in the flat areas and $40 \mathrm{~m}^{2}$ in curved areas.

The risks that occur during the construction are similar to ones at the construction of tunnels: large-scale failure of the rock cover, large deformations of the cavern wall, irruption of the water and impact on water resources in the surrounding area. The risks that may occur during the operation are: failure ofthe rock mass, uplift of the rock cover, failure of the rock between two caverns, large deformation or destruction of the steel lining, unequally deformation of the LRC structure because of the rock heterogeneity and the draining system does not work. Since the risks during the operation are decisive, the risks during the construction are not considered explicitly in this paper. The LRC concept should provide a safe and environmentally friendly modefor gas storage. Since the gas should never been in contact with the environment, the gas storage is designed as a closed system. The caverns and the entire gasnetwork are impermeable.

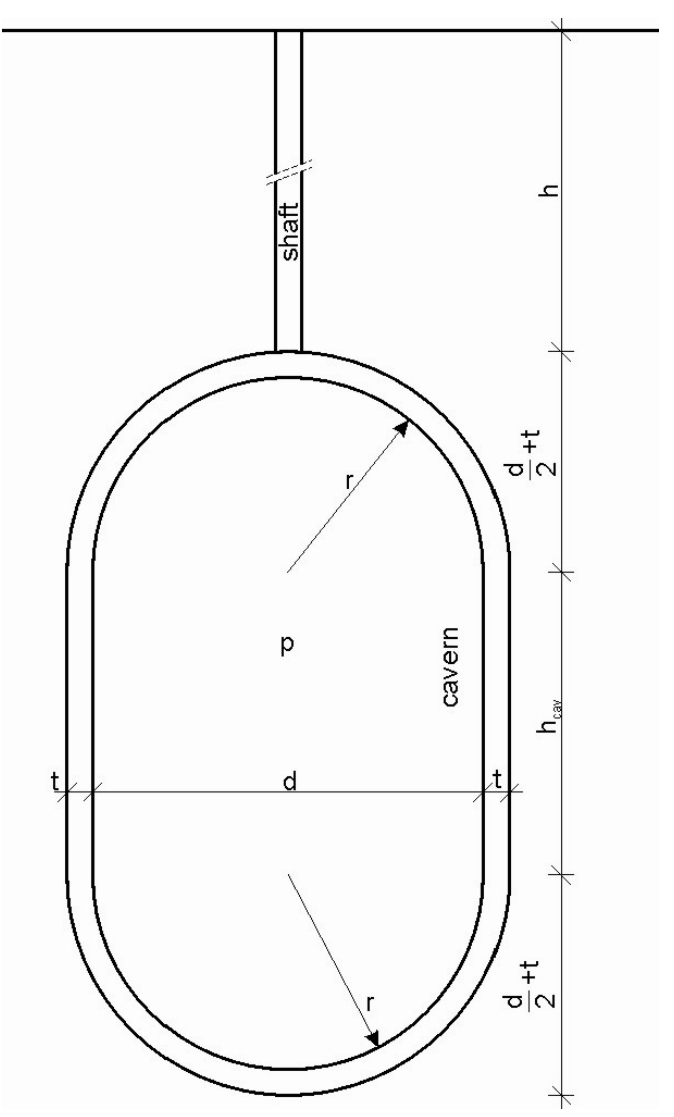

Fig. 2. Schematic view of the underground natural gas storage UGSG 


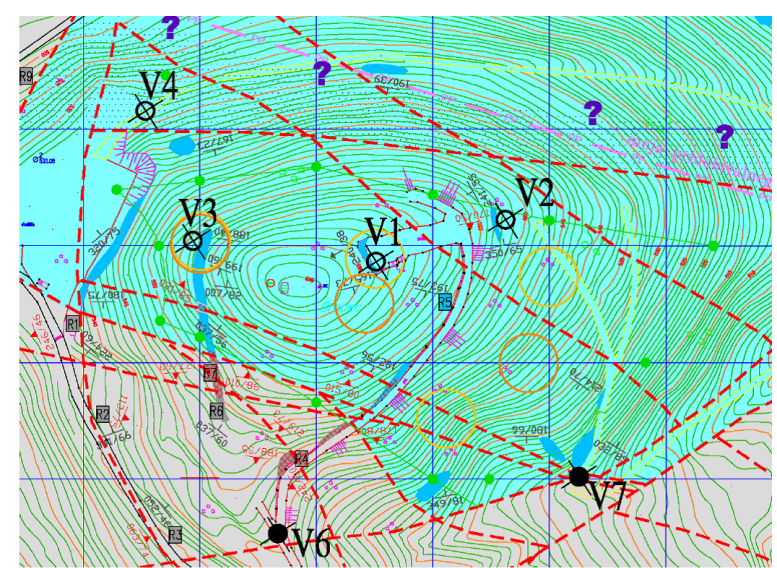

Fig. 3. Geological map with marked outcrops, boreholes and sections

\section{FIELD ACTIVITIES}

These boreholes were geologically and geo-technically inventoried, and besides lithology, cracks were also registered: their direction, thickness, filler, and frequency. RQD of the core was measured and a particular stress was laid on presence of broken zones and appearance of different minerals (pyrite, ferro-oxides, hydroxides, and calcite). Samples for laboratory researches were taken from boreholes and different geotechnical and hydrotechnical researches were carried out within boreholes themselves Figures 3 and 4.

\section{PRESSIOMETRCIC MEASUREMENTS}

Pressiometric researches were performed in boreholes. Results showed that elasticity modules $\left(\mathrm{E}_{0}\right)$ range between $0.103 \mathrm{GPa}$ and $71.36 \mathrm{GPa}$.

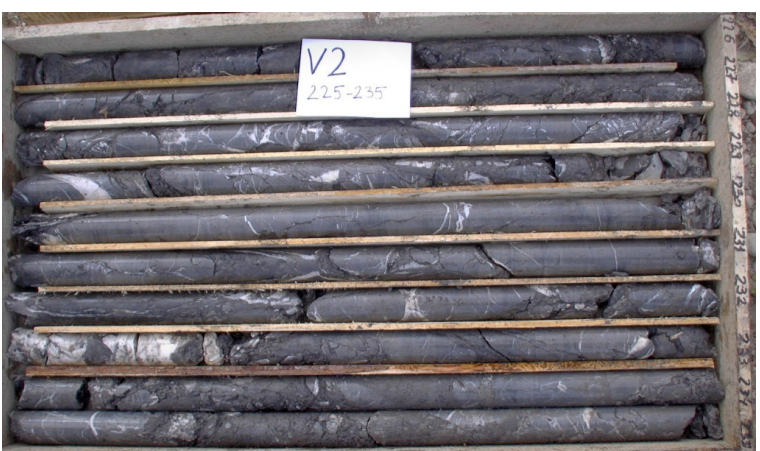

Fig. 4. Characteristic core from the borehole

Lower values are typical for limestone-dolomite breccia's with clay-marl binder, clay and marl, and highly cracked rocks; higher values appear in compact dolomites, limestone and breccia's with carbon binder.

It is typical for rocks [8] with more cracks and for rocks with lower elasticity module, that the discharge module $\left(\mathrm{E}_{\mathrm{ur}}\right)$ is up to 10 times higher than load module; for compact rocks, the discharge module is 2-3 times higher.

Comparison with results of elasticity module measurements with a pressiometer $\left(\mathrm{E}_{0}\right)$ and modules, measured in a laboratory shows that range and order of magnitude of measured values are similar. Direct comparison between measured modules was only possible on the depth of $192.5 \mathrm{~m}$ where breccia's carbons with different binder appear. Value measured with a pressiometer is $8.3 \mathrm{GPa}$ and value obtained in the laboratory is $66.9 \mathrm{GPa}$.

Reason for such deviations lay in a fact that elasticity module of the hill was measured in pressiometric measurements, and these results are

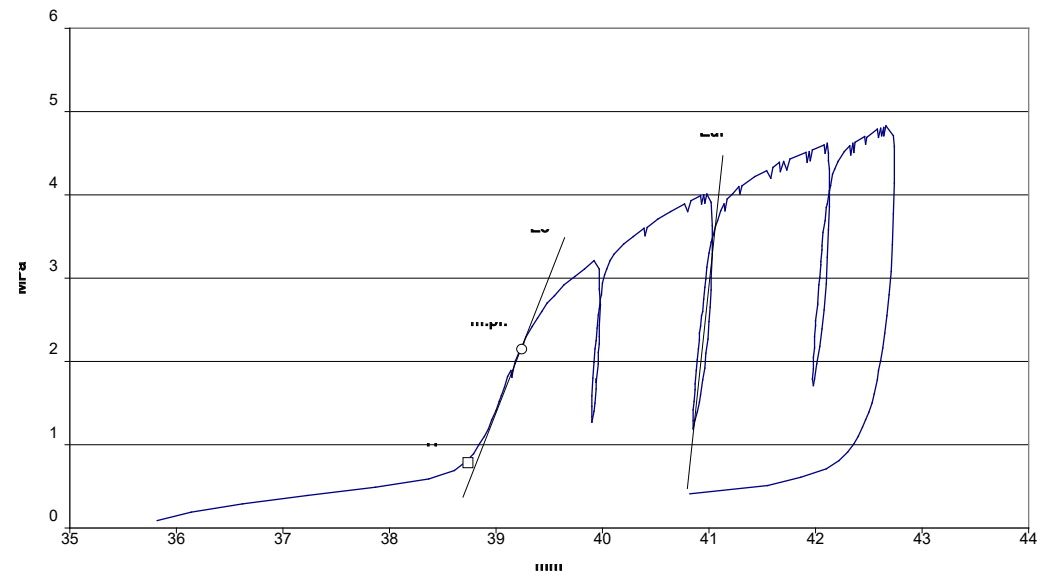

Fig. 5. Results of pressiometric measurements in the borehole 
indirectly influenced by spatial variations such as presence of cracks, changes in lithology etc. Influence of spatial variations is substantially lower in a laboratory specimen, and consequently the elasticity module is higher.

Pressiometric measurements come closer to the real value of the module of a compact rock with discharge module, $\left(\mathrm{E}_{\mathrm{ur}}\right)$, which is $42.6 \mathrm{GPa}$ in our case, and this is much closer to the laboratory value. Part of results of researches performed is summarized in Figure 5.

\section{GEOPHYSICAL MEASUREMENTS}

In the area of forecasted construction of the UGSG geo-physical measurements have been carried out as well, namely seismic crosshole and geo-electrical crosshole among existing research boreholes. Two seismic and two geoelectric mappings have been measured out. Objective of researches was to find out eventual anomalous zones in prevailingly carbon rocks caused by some layers of sediments, mostly marl and slate sediments. We have not discovered existence of larger fault zones with geophysical measurements.

\section{HYDROGEOLOGICAL MEASUREMENTS}

In the context of hydro geological measurements pour-in tests in different depths have been carried out. Besides this, a series of measurements for determination of underground water level have also been performed. Results of pour-in tests were evaluated upon different methods [9]. On the basis of measured values tested rocks can be classified in the class of semi-permeable ones with co-efficient of permeability between $10^{-5}$ in $10^{-6} \mathrm{~m} \cdot \mathrm{s}^{-1}$ ).

\section{LABORATORY TESTS}

Within the framework of laboratory tests, the following tests have been carried out on samples taken from the boreholes in the report [10].

- $\quad$ single-axis pressure solidness $\left(\sigma_{c}\right)$;

- $\quad$ single-axis tensile yield stress $\left(\sigma_{t}\right)$;

- volume mass $(\gamma)$

- $\quad$ elasticity module (E);

- poisson co-efficient $(v)$.

\section{DETERMINATION OF THE ROCK MASS PARAMETERS}

Data obtained from geological mapping and the geological inventory of the core wells,confirming act and limestone dolomites, are presented in Table 1. After all needed geological data were obtained, rock mass parameters were determined on the basis of the generalized Hoek-Brown failure criterion $[11,12]$. The computer program RocLab was applied [13]. The geological strength index GSI was 46. The MohrCoulomb strength parameters are derived, i.e. the cohesion c was $900 \mathrm{kPa}$ and the friction angle $\varphi$ was $39^{\circ}$. Finally, calculated were the rock mass parameters: the rock mass tensile strength $\sigma \mathrm{t}$ was $0.092 \mathrm{MPa}$, the uniaxial rock mass compressive strength $\sigma \mathrm{c}$ was $2.29 \mathrm{MPa}$, the global rock mass compressive strength $\sigma \mathrm{c}$ was $8.13 \mathrm{MPa}$ and the rock mass deformation modulus Erm was 10.70 $\mathrm{GPa}$. In the following, the UGSG must be designed as is shown [14] in the diagram Figure 6.

Table 1. Laboratory results

\begin{tabular}{|c|c|c|c|c|c|c|}
\hline \multicolumn{2}{|c|}{ Material } & \multirow{2}{*}{$\begin{array}{c}\text { Unit weight } \\
\mathbf{y} \\
\text { kN.m-3 } \\
\end{array}$} & \multirow{3}{*}{$\begin{array}{c}\begin{array}{c}\text { Uniaxial compressive } \\
\text { strength } \\
\boldsymbol{\sigma}_{\mathrm{c}}\end{array} \\
\mathrm{MPa} \\
25,9-126,8\end{array}$} & \multirow{3}{*}{$\begin{array}{c}\begin{array}{c}\text { Uniaxial tensile } \\
\text { strength } \\
\boldsymbol{\sigma}_{\mathbf{t}}\end{array} \\
\mathrm{MPa} \\
2,4-9,1\end{array}$} & \multirow{3}{*}{$\begin{array}{c}\begin{array}{c}\text { Elastic } \\
\text { modulus } \\
\mathrm{E}\end{array} \\
\mathrm{MPa} \\
53600-98520\end{array}$} & \multirow{3}{*}{$\begin{array}{c}\begin{array}{c}\text { Poisson } \\
\text { coefficient } \\
\mathbf{v}\end{array} \\
0,11-0,49\end{array}$} \\
\hline \multirow{3}{*}{ Limestone } & & & & & & \\
\hline & Range & $25.8-27.4$ & & & & \\
\hline & Average & 26.4 & 59,9 & 5,66 & 77263,7 & 0,23 \\
\hline \multirow{2}{*}{ Dolomite } & Range & $26.5-27,3$ & $16,1-94,3$ & $5,0-5,4$ & $56780-59750$ & $0,20-0,36$ \\
\hline & Average & 26,9 & 57,9 & 5,2 & 58265 & 0,28 \\
\hline \multirow{2}{*}{ Breccia's } & Range & $24,1-27,1$ & $17,2-142,9$ & $2,7-10,8$ & $3340-103000$ & $0,02-0,44$ \\
\hline & Average & 26,0 & 53,0 & 5,6 & 46225,5 & 0,17 \\
\hline \multirow{2}{*}{$\begin{array}{l}\text { Tectonic } \\
\text { breccia's }\end{array}$} & Range & $22,7-24,0$ & $1,0-1,8$ & 0,2 & & \\
\hline & Average & 23,4 & 1,4 & 0,2 & & \\
\hline \multirow{2}{*}{$\begin{array}{l}\text { Limy } \\
\text { siltstone }\end{array}$} & Range & 23,5 & 58,9 & & & \\
\hline & Average & 23,5 & 58,9 & & & \\
\hline
\end{tabular}




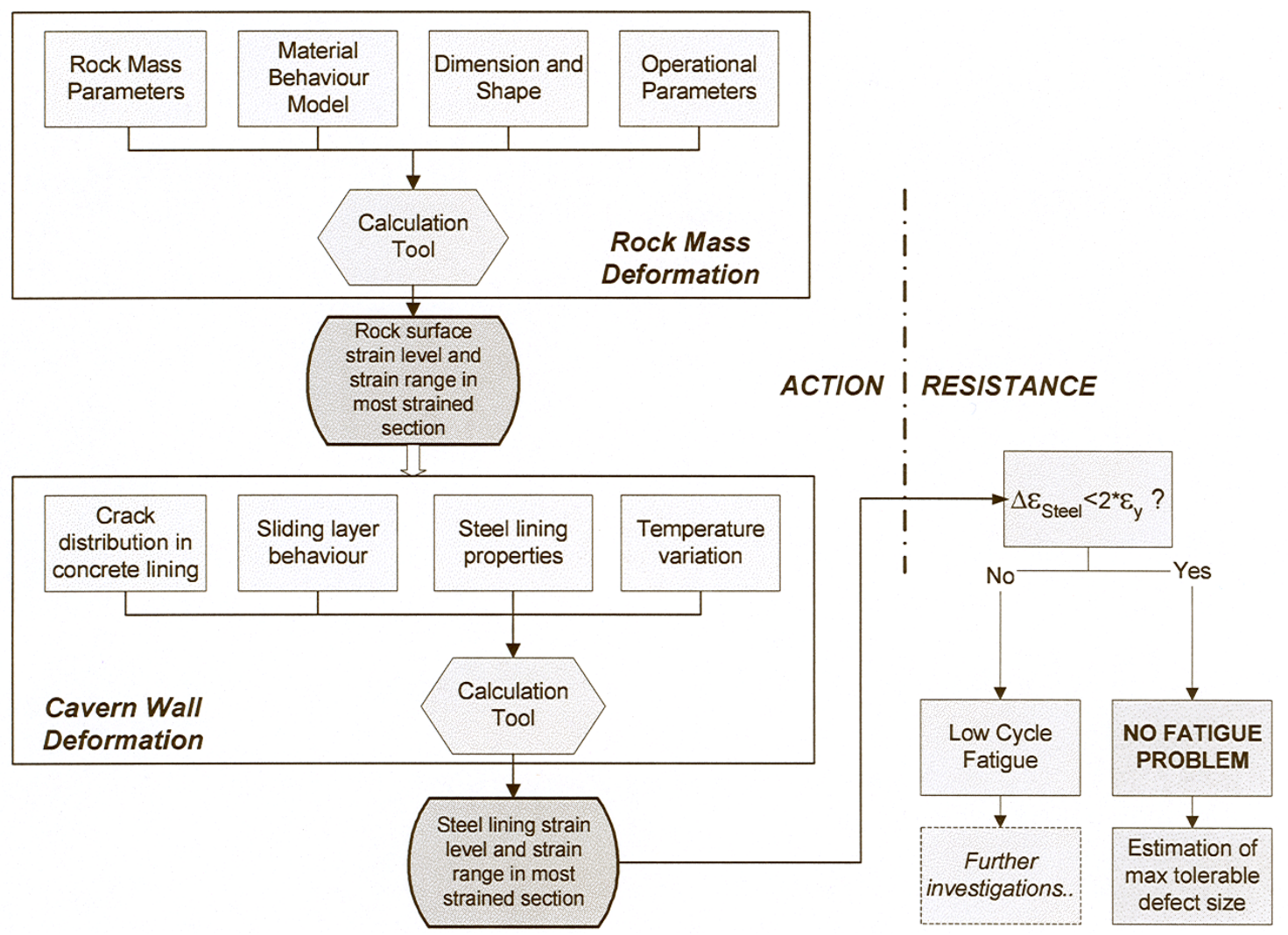

Fig. 6. UGSG design; $\Delta \varepsilon_{\text {steel }}-$ scale of deformation, $\varepsilon_{\mathrm{y}}-$ elastic deformation

\section{CONCLUSION}

The investigation for underground storage of gas (UGSG) in carbonate rocks was carried in Slovenia - Central Europe. The areas was geological surveyed and in addition structural boreholes were drilled up to the depth of $350 \mathrm{~m}$. The cores were logged with emphasis on stratigraphy, layering, rock joints, tectonic zones, RQD and addition characteristics samples were taken for the laboratory investigations. In boreholes geophysical, pressiometric and hydro-geological investigations were also carried out. In the area where the researches have been carried out, limestone, dolomites and breccia's are prevalent. Explorations confirmed that there is a possibility of building a high-pressure underground storage of gas (UGSG) and using applied mechanics for design LRC (Lined Rock Cavern) technology. In paper we defined that underground storage of gas it can be built for pressure between 15 and $20 \mathrm{MPa}$.

\section{REFERENCES}

1. Johansson J. High Pressure Storage of Gas in Lined Rock Caverns - Cavern Wall Design Principles.
Licentiate Thesis. Div. of Soil and Rock Mech., Royal Institute of Technology, Stockholm 2003.

2. Regueiro A., Jezerska L., Patino D., Perez-Orozco R., Necas J., and Zidek M. Experimental Study of the Viability of Low-Grade Biofuels in SmallScale Appliances. Sustainability, 9, 2017, 1-16.

3. Honus S., Kumagai S., Molnár V., Fedorko G. and Yoshioka T. Pyrolysis gases produced from individual and mixed PE, PP, PS, PVC, and PET-Part II: Fuel characteristics. Fuel, 221, 2018, 361-373.

4. Honus S., Kumagai S., Fedorko G., Molnár V. and Yoshioka T. Pyrolysis gases produced from individual and mixed PE, PP, PS, PVC, and PET—Part I: Production and physical properties. Fuel, 221, 2018, 346-360.

5. Honus S., Jursova S., Nemcek O. and Husakova $\mathrm{N}$. The study of the effects of burner design modifications on the course of gaseous fuel combustion making use of a laboratory combustion chamber. Proc. of Energy clean Technol. Conf. SGEM 2016, Sofia, Bulgaria 2016, 753-60.

6. Husakova N. Tools For Effective Application Of Eco-Logistics. Proc. of Carpathian Logist. Congr. (CLC 2013), Ostrava, Czech Republic, 2014, 80-83.

7. Vrlikova J. and Husakova N. Collection - process of reverse logistics and its solution for the selected type 
of waste. Proc. of Carpathian Logist. Congr. (CLC 2015), Ostrava, Czech Republic, 2016, 531-535.

8. Hencher S. Practical Rock Mechanics. CRC Press Taylor \& Francis Group, 2016, 356 p.

9. Vižintin G., Ravbar N., Janež J., Koren E., Janež N., Zini L., Treu F. and Petrič M. Integration of models of various types of aquifers for water quality management in the transboundary area of the Soča/Isonzo river basin (Slovenia/Italy). Science of the total environment, 619/620, 2018, 1214-1225.

10. Sternad Ž. Final report on geological and geo-technical conditions in PSZP Zakov/Senovo area, RGP, Velenje 2016.
11. Hoek E. and Diederichs M.S., Empirical estimation of rock mass modulus. International Journal of Rock Mechanics and Mining Sciences, 43, 2006, 203-215.

12. Hlosta J., Zurovec D., Gelnar D., Zegzulka J. and Necas J. Thermal Conductivity Measurement of Bulk Solids. Chemical Engineering Technology, 40, 2017, 1876-1884.

13. Kravanja S. and Žlender B., Optimization of the underground gas storage in different rock environments, WIT Transactions on the built environment, $125,2012,15-26$.

14. Noren C. Underground Storage of Natural Gas in Lined Rock Cavern in Brestanica Area. NCC, Stockholm, 2006. 